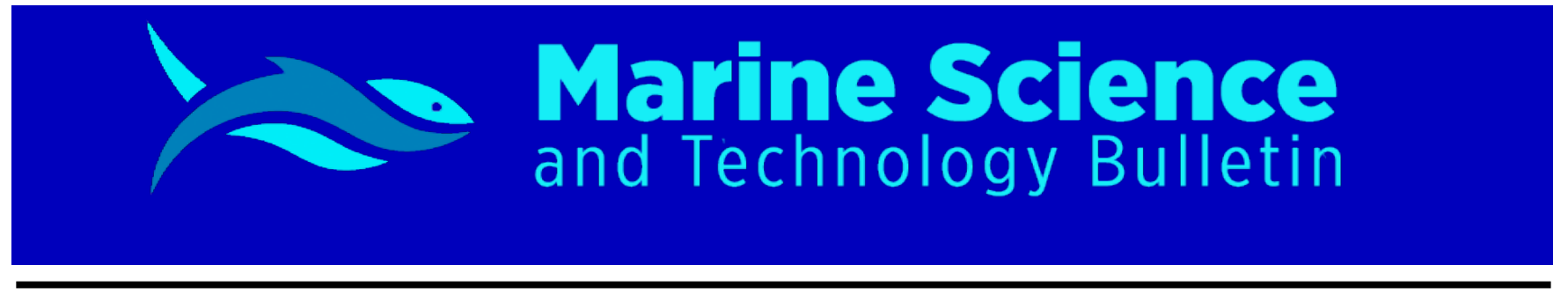

RESEARCH ARTICLE

\title{
Determination of shellfish consumption preferences and habits in Erzurum province
}

\author{
Pınar Oğuzhan Yıldız ${ }^{*}$ (D) Gökhan Arslan ${ }^{1}$ (D) \\ ${ }^{1}$ Atatürk University, Fisheries Faculty, Erzurum, Turkey
}

\section{A R T I C L E IN F O \\ Article History: \\ Received: 30.06.2020 \\ Received in revised form: 22.08.2020 \\ Accepted: 07.09.2020 \\ Available online: 22.09.2020}

\section{Keywords:}

Erzurum

Shellfish

Consumption preferences

\begin{abstract}
A B S T R A C T
The purpose of this research is to determine the shellfish consumption preferences and habits between November 2019 and February 2020 in Erzurum province. A survey consisting of 15 questions was asked face to face with 122 people randomly selected to obtain some results relevant to participant's average monthly income, educational background, their occupational status. The relationships between the demographic characteristics of the participants and the consumption habits of shellfish were analyzed with the Chi-square test. When demographic data were examined, $46.72 \%$ of the participants were female, $53.28 \%$ were male. The highest age group with a rate of $41,80 \%$ is $21-30$ years old, the lowest being $61-70$ years old with a rate of $4,92 \%$ has been identified as the group. When the education levels of the participants were analyzed, it was determined that the highest rate (60.65\%) was belonged to university graduates. According to the result, $83.3 \%$ of the participants stated that they had not information about the nutritional value of shellfish. Also, it was determined that $66.2 \%$ of the sharers preferred mussels compared to crustaceans. This study in Erzurum, where the consumption of shellfish is very low compared to the seashore cities, is also an important data source in terms of providing ideas for different researches and aquaculture systems.
\end{abstract}

Please cite this paper as follows:

Oğuzhan Yıldız, P., Arslan, G. (2021). Determination of shellfish consumption preferences and habits in Erzurum province. Marine Science and Technology Bulletin, 10(1): 16-22.

\section{Introduction}

Since aquaculture is rich in protein, vitamins and minerals, it is among the foods that have an important place in human nutrition and are recommended for health. Aquaculture in terms of consumption; includes molluscs, crustaceans and all

\footnotetext{
* Corresponding author

E-mail address: pinaroguzhan@atauni.edu.tr (P. Oğuzhan Yıldız)
}

kinds of fish and marine mammals. (Baysal, 2004; Oğuzhan et al., 2006).

Shellfish have been used as a food source of people since ancient times (Başçınar, 2007). Due to its animal origin, it is among the foods with high biological value, especially recommended for the nutrition of children. They contain 
mainly protein, iodine, phosphorus, zinc, vitamin E, niacin, vitamin B12, unsaturated fatty acids, omega-3, omega-6, docosahexaenoic acid (DHA), eicosapentaenoic acid (EPA) and many bioactive beneficial components. Because they contain these extremely valuable and useful ingredients, they are classified as more valuable than many animal foods and are in the category of "functional foods", also referred to as nutraceuticals in recent years (Tokuşoğlu, 2016).

Shrimp, crab, lobster, mussel and oyster are the main shellfish products. World fish production (fish, crustaceans and molluscs) is 172.7 million tons in 2017. In 2017, 53.4 million tons of world aquaculture production was fish (66.6\%), 17.4 million tons of molluscs (21.7\%), 8.4 million tons of crustaceans (10.5\%) and 0.9 million. tonnes consisted of other aquatic animal species (1.1\%). The production of crustaceans and molluscs is also important in marine fish, which is mostly composed of marine fish. In our country, $21.8 \%$ of the total marine products caught production in 2018 was made up of other aquaculture group other than fish. The species with the highest production in this group are striped venus and sea snails, both of which are caught in the Black Sea (Anonymous, 2019).

In this study, it was aimed to determine the consumption preferences and habits of shellfish products by conducting a survey in the form of question and answer to consumers in Erzurum.

Based on this survey, an important place in the world aquaculture production units and shellfish which is high compared to the return of fish and molluscs in Turkey is thought to be done research to increase aquaculture and consumption.

\section{Material and Methods}

This study was conducted between November 2019 and February 2020 in order to determine the consumption preferences and habits of shellfish consumption in Erzurum. Erzurum is a province that covers $25,066 \mathrm{~km}^{2}$ area in the Eastern Anatolia Region of Turkey. It is bordered by the provinces of Kars and Ağrı to the east, Muş and Bingöl to the south, Erzincan and Bayburt to the west, Rize and Artvin to the north and Ardahan to the northeast. Continental climate rules in the province with long and harsh winters, and short and mild summers. Agricultural activities are carried out in the province. Most of the grain types are cultivated of wheat, barley and rye. Among the industrial plants, mostly sugar beet, potato and sunflower are cultivated. Apple, pear, walnut, apricot, plum, cherry, cherry and cranberry are grown. Livestock in in the province produced. Food industries include beekeeping and trout farming (Anonymous, 2020).
The material of the study consists of data obtained from a survey with a total of 122 individuals (57 women and 65 men). The study was achieved by asking total 15 questions to participants in survey. 10 questions were asked on the seafood and shellfish consumption habits, 5 questions asked to measure demographic characteristics to better understand the underlying factors about consuming habits. The data obtained from the survey were analyzed with the Chi-square test using the SPSS package program and statistical significance level was accepted as p <0.05 (Sümbüloğlu and Sümbüloğlu, 2019).

\section{Results and Discussion}

\section{Socio-Demographic Features of Consumers}

\section{Participating in the Survey}

$46.72 \%$ of the consumers participating in the survey are women and $53.28 \%$ are men. While the lowest age group of the participants were $61-70$ age with a rate of $4.92 \%$, the highest was determined as $21-30$ age with $41.80 \%$. $60.65 \%$ of the participants of survey were graduated from a university, $4.92 \%$ of the participants were graduated from a primary school, $13.11 \%$ of the participants were graduated from a high school, and $21.32 \%$ of the participants were graduated from postgraduate. $15.57 \%$ of the participants are official, $7.38 \%$ are self-employed, $41.80 \%$ are students, $13.94 \%$ are retired, $8.20 \%$ are housewives, and $13.11 \%$ are from other occupational groups. They were found to be considering the income levels, $32.79 \%$ of 1000 TRY and below, $14.76 \%$ of $1001-2000$ TRY, $26.23 \%$ of $2001-3000$ TRY, $11.47 \%$ of $3001-4000$ TRY, and $14.7 \%$ of 4001 TRY and above (Table 1 ).

Saka and Bulut (2020) reported that $57.6 \%$ of the participants were male and $42.4 \%$ were female. When the ages of the participants were compared, $30.8 \%$ were in the 19-29 age group while $27.8 \%$ were in the $30-49$ age group. When the educational status was examined, it was determined that $33.4 \%$ graduated from high school or equivalent schools and $19.1 \%$ graduated from undergraduate programs. When the professions of the participants were researched, $27 \%$ were students, $20 \%$ were self-employed, $18.6 \%$ were workers, $13.6 \%$ were homemakers, $13.3 \%$ were public officers, and $7 \%$ were retired.

In the study in Çan district of Çanakkale, the income levels were determined $18.3 \%$ of 2000 TRY and below, $19.5 \%$ of 2000 3500 TRY, $41.2 \%$ of $3500-5000$ TRY, and $21 \%$ of 5000 TRY and above (Selvi et al., 2019). 


\section{Shellfish Products Preference and Consumption}

\section{Habits of Consumers Participating in the Survey}

Depending on the age, the analysis of the answers given by the participants to the question "How often do you consume seafood?" is shown in Table 2.

As a result of the Chi-square independence test for the answers given by the participants to the question "How often do you consume seafood?" a significant difference was found between the answers given depending on the age $(\mathrm{p}<0.05)$. While $66.7 \%$ of participants between the ages of 51-60 say they consume every fifteen days, this rate is $9.8 \%$ for participants between the ages of 21-30. They responded "How often do you consume seafood?" $27.5 \%$ of the respondents to the question once a week, $35.83 \%$ once a month, $5.83 \%$ twice a week, $12.5 \%$ twice a month and $18.34 \%$ once a year in a study in Palu district of Elazig province (Karaton Kuzgun and Demirbağ, 2018).

In another study in Antalya province, the frequency of seafood consumption was determined to be $43.67 \%$ once every two weeks and $26.81 \%$ once a week (Arslan and Izci, 2016). The answers given to this question in the studies conducted in different regions are thought to cause from geographical conditions, table culture and habits.

Depending on gender, the analysis of the answers given by the participants to the question "Which of the crustaceans and molluscs do you prefer more?" is given in Table 3 .

As a result of the Chi-square independence test for the answers given by the participants to the question "Which of the crustacean and molluscs would you prefer more?", a significant difference was found between the answers given depending on
Table 1. Gender, age, educational status, income level, and occupational distributions of the participants

\begin{tabular}{lrr}
\hline Gender & N & \% \\
\hline Male & 65 & 53.3 \\
Female & 57 & 46.7 \\
\hline Age & & \\
\hline$<21$ & 14 & 11.5 \\
$21-30$ & 51 & 41.8 \\
$31-40$ & 22 & 18.1 \\
$41-50$ & 11 & 9.0 \\
$51-60$ & 18 & 14.7 \\
$61-70$ & 6 & 4.9 \\
\hline Educational Status & & \\
\hline Primary school & 6 & 4.9 \\
High school & 16 & 13.1 \\
University & 74 & 60.7 \\
Postgraduate & 26 & 21.3 \\
\hline Income Level & & \\
\hline$<1000$ TRY & 40 & 32.8 \\
1001-2000 TRY & 18 & 14.7 \\
2001-3000 TRY & 32 & 26.3 \\
3001-4000 TRY & 14 & 11.5 \\
$>$ 4000 TRY & 18 & 14.7 \\
\hline Occupational & & \\
\hline Official & 19 & 15.6 \\
Free & 9 & 7.4 \\
Student & 51 & 41.8 \\
Retire & 17 & 13.9 \\
Housewife & 10 & 8.2 \\
Other & 16 & 13.1 \\
\hline & &
\end{tabular}

Table 2. Shellfish consuming frequency according to the age group

\begin{tabular}{|c|c|c|c|c|c|c|}
\hline \multirow{2}{*}{ Age } & & \multicolumn{4}{|c|}{ How often do you consume? } & \multirow{2}{*}{ Total } \\
\hline & & Once a week & Fortnightly & Once a month & Once a year & \\
\hline \multirow{2}{*}{$<21$} & Person & 2 & 2 & 8 & 2 & 14 \\
\hline & $\%$ & 14.3 & 14.3 & 57.1 & 14.3 & 100 \\
\hline \multirow{2}{*}{$21-30$} & Person & 10 & 5 & 24 & 12 & 51 \\
\hline & $\%$ & 19.6 & 9.8 & 47.1 & 23.5 & 100 \\
\hline \multirow{2}{*}{$31-40$} & Person & 8 & 6 & 6 & 2 & 22 \\
\hline & $\%$ & 36.4 & 27.3 & 27.3 & 9.1 & 100.0 \\
\hline \multirow{2}{*}{$41-50$} & Person & 4 & 4 & 3 & 0 & 11 \\
\hline & $\%$ & 36.4 & 36.4 & 27.3 & 0 & 100 \\
\hline \multirow{2}{*}{$51-60$} & Person & 3 & 12 & 2 & 1 & 18 \\
\hline & $\%$ & 16.7 & 66.7 & 11.1 & 5.6 & 100 \\
\hline \multirow{2}{*}{ 61-70 } & Person & 3 & 0 & 0 & 3 & 6 \\
\hline & $\%$ & 50 & 0 & 0 & 50 & 100 \\
\hline \multirow{2}{*}{ Total } & Person & 30 & 29 & 43 & 20 & 122 \\
\hline & $\%$ & 24.6 & 23.8 & 35.2 & 16.4 & 100 \\
\hline
\end{tabular}

Note: Pearson Chi-square: $45,110 \mathrm{p}<0.05$ 
Table 3. Consuming preferences according to gender

\begin{tabular}{|c|c|c|c|c|c|c|c|}
\hline \multirow{2}{*}{ Gender } & & \multicolumn{5}{|c|}{ Which of the crustaceans and molluscs would you prefer? } & \multirow{2}{*}{ Total } \\
\hline & & Shrimp & Crab & Lobster & Mussel & None & \\
\hline \multirow[t]{2}{*}{ Male } & Person & 10 & 0 & 1 & 43 & 11 & 65 \\
\hline & $\%$ & 15.4 & 0 & 1.5 & 66.2 & 16.9 & 100 \\
\hline \multirow[t]{2}{*}{ Female } & Person & 10 & 6 & 0 & 28 & 13 & 57 \\
\hline & $\%$ & 17.5 & 10.5 & 0 & 49.1 & 22.8 & 100 \\
\hline Total & Person & 20 & 6 & 1 & 71 & 24 & 122 \\
\hline
\end{tabular}

Note: Pearson Chi-square: 9,853 $\mathrm{p}<0.05$

Table 4. Factors affecting the preference to buy shellfish

\begin{tabular}{|c|c|c|c|c|c|c|c|}
\hline \multirow{2}{*}{ Gender } & & \multicolumn{5}{|c|}{ What do you pay attention to when buying shellfish? } & \multirow{2}{*}{ Total } \\
\hline & & Cleaning of the place taken & Freshness & Price & Species & Other & \\
\hline Male & Person & 9 & 22 & 16 & 10 & 8 & 65 \\
\hline \multirow[t]{2}{*}{ Female } & Person & 17 & 28 & 3 & 4 & 5 & 57 \\
\hline & $\%$ & 29.8 & 49.1 & 5.3 & 7 & 8.8 & 100 \\
\hline Total & Person & 26 & 50 & 19 & 14 & 13 & 122 \\
\hline
\end{tabular}

Note: Pearson Chi-square: $14,879 \mathrm{p}<0.05$

Table 5. Consuming preferences of shellfish species according to the age group

\begin{tabular}{|c|c|c|c|c|c|c|c|}
\hline \multirow{2}{*}{ Age } & & \multicolumn{5}{|c|}{ Which of the crustaceans and molluscs would you prefer more? } & \multirow{2}{*}{ Tota } \\
\hline & & Shrimp & Crab & Lobster & Mussel & None & \\
\hline$<21$ & Person & 0 & 2 & 0 & 10 & 2 & 14 \\
\hline \multirow{2}{*}{$21-30$} & Person & 5 & 0 & 1 & 41 & 4 & 51 \\
\hline & $\%$ & 9.8 & 0 & 2 & 80.4 & 7.8 & 100 \\
\hline \multirow{2}{*}{$41-50$} & Person & 5 & 0 & 0 & 4 & 2 & 11 \\
\hline & $\%$ & 45.5 & 0 & 0 & 36.4 & 18.2 & 100 \\
\hline \multirow{2}{*}{$51-60$} & Person & 1 & 2 & 0 & 5 & 10 & 18 \\
\hline & $\%$ & 5.6 & 11.1 & 0 & 27.8 & 55.6 & 100 \\
\hline Total & $\%$ & 16.4 & 4.9 & 0.8 & 58.2 & 19.7 & 100 \\
\hline
\end{tabular}

Note: Pearson Chi-square: $58,282 \mathrm{p}<0.05$

gender $(\mathrm{p}<0.05)$. While $66.2 \%$ of men prefer the most mussel response, this rate is $49.1 \%$ for women. It was found that they did not prefer other crustaceans and molluscs. This situation is caused the fact that the consumption of shellfish is not common in our country and that there is more mussel consumption in the settlements that have a coast. In the study in Ardahan province, the most consumed seafood was found to be mussels with $11.92 \%$ (Kılıç et al., 2019). They found that consumers in Ankara province consumed mussels with $47.50 \%$, followed by squid and shrimp respectively (Yavuz et al., 2015). In another study in the province of Burdur has been reported mussels with $71.40 \%$, shrimp with $39.30 \%$, squid with $25 \%$, octopus with $7.10 \%$, lobster with $3.60 \%$ and crab with $3.60 \%$ (Orhan and Yüksel, 2010).

Depending on gender, the analysis of the answers given by the participants to the question "What do you pay attention to when buying shellfish?" is given in Table 4.

As a result of the Chi-square independence test for the answers given by the participants to the question "What do you 
pay attention to when buying shellfish?", a significant difference was found between the answers given depending on gender $(\mathrm{p}<0.05)$. While $49.1 \%$ of women respond to freshness, this rate is $33.8 \%$ for men. $82 \%$ of individuals in the province of Denizli reported that they pay attention to freshness while buying fish (Telli, 2018). In the central district of Kahramanmaraş province, $73 \%$ of the participants were found to pay attention to freshness while purchasing fish (Beyazbayrak, 2014). They emphasized that the people who buy fish in Rize province attach great importance to keeping the fish fresh (Temel, 2014). The survey results in different regions are similar to our results. Aydin and Bashimov (2020) reported that the freshness of the fish is very effective while buying fish consumers in urban areas of Mary city in Turkmenistan.

Depending on the age, the analysis of the answers given by the participants to the question "Which of the crustaceans and molluscs would you prefer more?" is given in Table 5 .

In terms of the answers given to "Which of the crustaceans and molluscs do you prefer more?", it was observed that there was a significant difference between the ages in accordance to the Chi-square independence test $(\mathrm{p}<0.05)$. While $80.4 \%$ of the participants between the ages of 21-30 say they consume more mussels, this is $27.8 \%$ for the age group of $51-60$.

Depending on the education level, the analysis of the answers given by the participants to the question "Do you have information about shellfish?" is given in Table 6.

In terms of the answers given to "Do you have information about shellfish?", it has been revealed that there is a significant difference between the educational status as a result of the Chisquare independence test $(\mathrm{p}<0.05)$. While $87.5 \%$ of the secondary education graduates give no answer, this rate is $30.8 \%$ for graduate graduates. This situation thought to be due
Erzurum province does not have a seaside, the consumption of shellfish as human food is not widespread enough and due to the table culture. Kılıç et al. (2019) were reported that $78.48 \%$ of consumers in Ardahan province had knowledge about fish meat, while $19.21 \%$ did not.

Table 6. Knowledge level of consumers on the shellfish according to the education level

\begin{tabular}{llrrr}
\hline \multirow{2}{*}{ Educational Status } & & \multicolumn{2}{c}{$\begin{array}{c}\text { Do you have } \\
\text { information about } \\
\text { shellfish? }\end{array}$} & Total \\
\cline { 2 - 3 } & & Yes & No & \\
\hline Primary school & Person & 1 & 5 & 6 \\
& $\%$ & 16.7 & 83.3 & 100 \\
\hline High school & Person & 2 & 14 & 16 \\
& $\%$ & 12.5 & 87.5 & 100 \\
\hline University & Person & 32 & 42 & 74 \\
& $\%$ & 43.2 & 56.8 & 100 \\
\hline Postgraduate & Person & 18 & 8 & 26 \\
& $\%$ & 69.2 & 30.8 & 100 \\
\hline Total & Person & 53 & 69 & 122 \\
& $\%$ & 43.4 & 56.6 & 100 \\
\hline
\end{tabular}

Note: Pearson Chi-square: 15,858 p $<0.05$

The analysis of the answers given by the participants to the question "How often do you consume seafood?" depending on their income levels is given in Table 7.

As a result of the Chi-square independence test in terms of the answers given to the question "How often do you consume?", it was revealed that there is a significant difference in terms of income levels $(\mathrm{p}<0.05)$. While $42.9 \%$ of individuals with 3001 4000 TRY income level answer every fifteen days, this rate is $10 \%$ for individuals whose income level is below 1000 TRY. In study in Erzurum province, the frequency of fish consumption

Table 7. Shellfish consuming frequency according to the income level

\begin{tabular}{|c|c|c|c|c|c|c|}
\hline \multirow{2}{*}{\multicolumn{2}{|c|}{ Income level (TRY) }} & \multicolumn{4}{|c|}{ How often do you consume? } & \multirow{3}{*}{$\begin{array}{r}\text { Total } \\
40\end{array}$} \\
\hline & & \multirow{2}{*}{$\frac{\text { Once a week }}{5}$} & \multirow{2}{*}{$\begin{array}{c}\text { Fortnightly } \\
4\end{array}$} & \multirow{2}{*}{$\begin{array}{c}\text { Once a month } \\
21\end{array}$} & \multirow{2}{*}{$\frac{\text { Once a year }}{10}$} & \\
\hline$<1000$ & Person & & & & & \\
\hline & $\%$ & 12.5 & 10 & 52.5 & 25 & 100 \\
\hline \multirow[t]{2}{*}{$1001-2000$} & Person & 3 & 5 & 7 & 3 & 18 \\
\hline & $\%$ & 16.7 & 27.8 & 38.9 & 16.7 & 100 \\
\hline \multirow[t]{2}{*}{$2001-3000$} & Person & 9 & 11 & 7 & 5 & 32 \\
\hline & $\%$ & 28.1 & 34.4 & 21.9 & 15.6 & 100 \\
\hline \multirow[t]{2}{*}{$3001-4000$} & Person & 4 & 6 & 4 & 0 & 14 \\
\hline & $\%$ & 28.6 & 42.9 & 28.6 & 0 & 100 \\
\hline \multirow[t]{2}{*}{$>4001$} & Person & 9 & 3 & 4 & 2 & 18 \\
\hline & $\%$ & 50 & 16.7 & 22.2 & 11.1 & 100 \\
\hline \multirow[t]{2}{*}{ Total } & Person & 30 & 29 & 43 & 20 & 122 \\
\hline & $\%$ & 24.6 & 23.8 & 35.2 & 16.4 & 100 \\
\hline
\end{tabular}

Note: Pearson Chi-square: 25,704 p $<0.05$ 
Table 8. Consuming preferences of shellfish species according to the occupational group

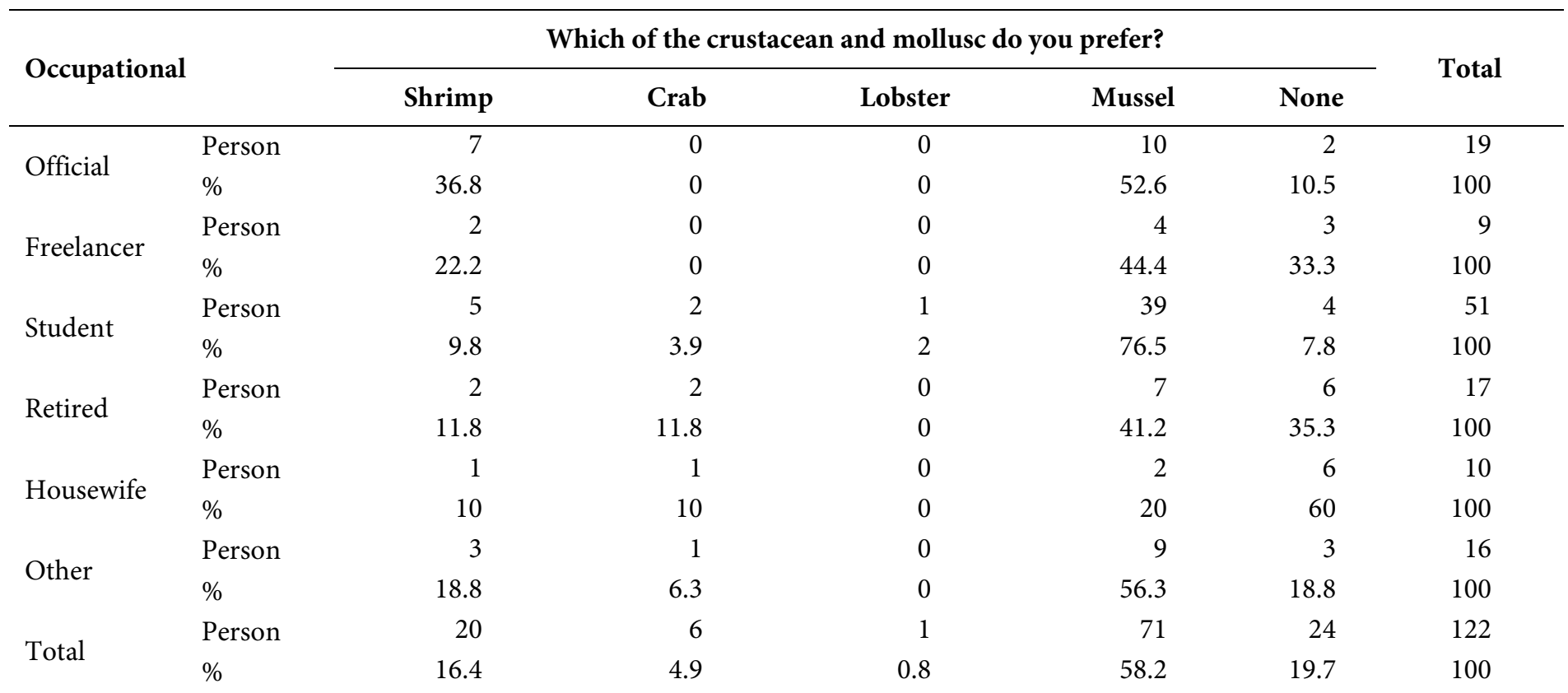

Note: Pearson Chi-square: $34,341 \mathrm{p}<0.05$

was determined to be $26.7 \%$ of those with an income of 3501 TRY and above consume fish once a week, this rate is $12.5 \%$ for those whose income is 2000 TRY and less (Karakulak et al., 2019).In another study Erzincan province, the rate of those who consume fish fortnightly is $50 \%$, the rate of those who consume fish once a month is $40 \%$, and the rate of those who consume fish once a week is $10 \%$ (Karakaya, 2020). Quasim et al. (2020) stated that $38.8 \%$ eat fish once a month, $32 \%$ two to three times a month, $20.6 \%$ four times a month, and $8.03 \%$ more than four times a month.

Depending on the profession groups, the analysis of the answers given by the participants to the question "Which of the crustacean and molluscs do you prefer?" is given in Table 8.

As a result of the Chi-square independence test conducted to determine whether there is a difference between the professional groups in terms of the answers given to the question "Which of the crustacean and molluscs do you prefer more?", it was revealed that there was a significant difference $(\mathrm{p}<0.05)$. It was determined that the participants consumed the most mussels with a rate of $76.5 \%$, while this rate was $20 \%$ for housewives in Table 8.

\section{Conclusion}

In conclusion, consumption of shellfish, especially rich in nutrition, is very low in our country compared to other seafood products. According to Turkey Statistical Institute (TurkStat, 2018) fisheries data; 628631 tons of seafood was put into consumption. $35.3 \%$ marine fish, $9.9 \%$ other seafood, $4.8 \%$ inland fisheries and $50 \%$ aquaculture products. While the average fish consumption per capita was 5.49 kilograms in
2017, it increased by 11.8 percent to 6.14 kilograms in 2018 . There are many reasons for this. In our study, it was seen that the lack of information about the nutritional content of shellfish is an important factor. The fact that most of the participants, whose education level is at the high school level, stated that they do not have information about shellfish products supports this situation. It is thought to be of benefit to increase shellfish training activities in the region. It is another result of our study in the responses that the consumption will increase if the prices of shellfish are reduced. The low use of shellfish in food culture in our country affects consumption significantly. These and similar studies are encouraging factors in the introducing and consumption of shellfish. This study in Erzurum, where the consumption of shellfish is very low compared to the seashore cities, is also an important data source in terms of providing ideas for different researches and aquaculture systems.

\section{Compliance with Ethical Standards}

\section{Authors' Contributions}

POY designed the study. GA performed statistical analysis. Both authors read and approved the final version of the article.

\section{Conflict of Interest}

The authors declare that there is no conflict of interest.

\section{Ethical Approval}

For this type of study, formal consent is not required. 


\section{References}

Anonymous. (2019). Su ürünleri sektör politika belgesi 20192023.

Anonymous, (2020). Erzurum ili. Retrieved on August 20, 2020 from https://tr.wikipedia.org/wiki/Erzurum

Arslan, M. \& İzci, L. (2016) .Antalya İli Su Ürünleri Tüketim Alışkanlıklarının Belirlenmesi. Eğirdir Su Ürünleri Fakültesi Dergisi, $\quad$ 12(1): $\quad$ 75-85. https://doi.org/10.22392/egirdir.246325

Aydın, A. \& Bashimov, G. (2020). Determination of fish consumption habits of consumers: Case study of Mary city, Turkmenistan. Marine Science and Technology Bulletin, $\quad$ 9(2): $118-124$. https://doi.org/10.33714/masteb.685436

Başçınar, N. (2007). Ülkemizdeki kabuklu ve yumuşakça su ürünleri üretimi ve ihracatı. Yunus Araştırma Bülteni, 7(2): 14-17.

Baysal, A. (2004). Beslenme. 10. Ed., Ankara, Turkey: Hatipoğlu Yayınevi, 566p.

Beyazbayrak, Z. (2014). Kahramanmaraş ili Merkez ilçede balık tüketim alışkanlıkları. Master Thesis. Kahramanmaraş Sütçü İmam University, Kahramanmaraş, Turkey.

Karakaya, E. (2020). Erzincan ili balık tüketim alışkanlıklarının belirlenmesi. Menba Kastamonu Üniversitesi Su Ürünleri Fakültesi Dergisi, 6(1): 18-29.

Karakulak, Y., Arslan, G. \& Yanı, T. (2019). Erzurum ili Merkez ilçelerinin su ürünleri tüketim davranışları üzerine araştırmalar. Acta Aquatica Turcica, 16(2): 290300. https://doi.org/10.22392/actaquatr.669336

Karaton Kuzgun, N. \& Demirbağ, A. (2018). Palu ilçesi balık tüketim alışkanlıklarının belirlenmesi. Uluslararası Palu Sempozyumu Bildiriler Kitabı, Elazı̆g, Turkey. pp. 205212.

Kılıç, E., Soylu, M. \& Uzmanoğlu, M. S. (2019). Ardahan ili su ürünleri tüketim alışkanlıklarının belirlenmesi. Turkish Journal of Agriculture - Food Science and Technology, 7(7): 1028-1039. https://doi.org/10.24925/turjaf.v7i7. $\underline{1028-1039.2536}$

Oğuzhan, P., Angiş, S., Haliloğlu, H. İ. \& Atamanalp, M. (2006). Gökkuşağı alabalığı (Oncorhynchus mykiss) filetolarında sıcak tütsüleme sonrası kimyasal kompozisyon değişimleri. Ege Üniversitesi Su Ürünleri Dergisi, 23(1/3): 465-466.
Orhan, H. \& Yüksel, O. (2010). Burdur İli su ürünleri tuketimi anket uygulaması. Suleyman Demirel Üniversitesi, Ziraat Fakultesi Dergisi, 5(1): 1-7.

Qasim, M., Qasim, S. \& Nazir, N. (2020). Factors affecting fish consumption of traditional subsistence fishers in Khyber Pakhtunkhwa, Pakistan. Marine Science and Technology Bulletin, 9(2): 178-187. https://doi.org/10.33714/masteb.744894

Saka, F. \& Bulut, M. (2020). Determination of fish consumption in Çanakkale. Marine Science and Technology Bulletin, 9(1): 7-14. https://doi.org/10.33714/masteb.658093

Selvi, K., Kandemir, G. \& Özdikmenli Tepeli, S. (2019). Determination of factors affecting on the fish consumption habit in rural areas. COMU Journal of Marine Science and Fisheries, 2(2): 132-141.

Sümbüloğlu, V. \& Sümbüloğlu, K. (2019). Bioistatistik. 13. Ed. Ankara, Turkey: Hatiboğlu Publishing. 299 p.

Telli, Ö. (2018). Denizli ili su ürünleri tüketim alı̧skanlıkları üzerine bir anket çalışması. Master Thesis. Süleyman Demirel University, Isparta, Turkey.

Temel, T. (2014). Rize İlinde hanelerin balık tuketimi üzerine etkili olan faktörlerin belirlenmesi. Master Thesis. Atatürk University,Erzurum, Turkey.

TurkStat. (2018). Fishery Statistics. Turkish Statistical Institute. Retrieved on August 20, 2020, from http://www.tuik.gov.tr

Tokuşoğlu, Ö. (2016). Kabuklu su ürünleri etleri ve kalite: Midye, istiridye, karides ve yengeç. Retrieved on February 14, 2020 from http://www.gida2000.com/kabuklu-su-urunleri-etlerive-kalite-midye-istiridye-karides-ve-yengec.html

Yavuz, G. G., Ataseven, Z. Y., Gül, U., Gülaç, Z. N. (2015). Su ürünleri tüketiminde tüketici tercihlerini etkileyen faktörler: Ankara ili örneği. Yunus Araştırma Builteni, 1(5): 73-82. 